\title{
Lessons of Korean Democratization for Modern Russia
}

\section{Democratic Transition: Differences and Similarities}

\author{
Konstantin V. Asmolov
}

\begin{abstract}
Amid debates over democratic transition in Eastern Asia the South Korean case more often than not drops out of sight. Meanwhile, the fall of the Syngman Rhee regime and the unsuccessful democratic experiment of the Second Republic, the modernization of the country during Pak Chung-hee rule and the attempts at democratization during the military dictatorship of Chun Doo-hwan are of great illustrative value.

The example of the Republic of Korea shows that modernization and democratization do not necessarily go hand in hand, while Pak's chuch'esŏng ideology is akin in some respects to Russia's "sovereign democracy." This article compares the democratization processes in South Korea and Eastern European countries in terms of external influences (above all, those by the great powers). This study identifies common features and distinctions in democratization in
\end{abstract}

Konstantin V. Asmolov, PhD in History

Institute of Far Eastern Studies of the Russian Academy of Sciences (IFES RAS), Moscow, Russia. Korean Studies Center, Senior Research Fellow

SPIN-RSCI: 9256-6834

Researcher ID: G-5161-2019

ORCID: 0000-0003-1584-2748

IstinaResearcherID (IRID): 5857994

E-mail: kvasm@mail.ru; asmolov@ifes-ras.ru

Tel.: (+7) 49912900 77; (+7) 9776435548

Address: 32 Nakhimovsky Proscpect, Moscow 117997, Russia

DOI: 10.31278/1810-6374-2019-17-2-174-200 
South Korea and Russia. The main common feature is the lack of a durable tradition of democracy similar to that in Europe, which has caused poor understanding of the process itself and occasional errors in adapting theoretical basics to the traditional conditions of these countries. As a result, in both countries the departure from authoritarian rule did not entail a direct transition to democracy.

Key words: South Korea, modernization theory, democratization, Pak Chunghee, chuch'esŏng ${ }^{1}$

The gradual shaping of the 21st century's world order has generated new doubts about the (academic) justifiability C of models and theories that seemed absolutely correct just recently. In many respects this concerns the theory of modernization and the ensuing theory of democratic transition, which some authors (Kapustin, 2001) view as an unsuccessful reanimation of the past.

In fact, a significant part of publications devoted to democratic transition in East Asia analyzes rather the transition of the former socialist bloc countries, while ignoring other options of movement towards democracy, including the South Korean one. The fall of the Eastern bloc riveted the transitologists' eyes precisely to these events (Saxonberg and Linde, 2003), while other options apparently escaped their attention. Markwick (1996) says that many former Sovietologists have turned into transitologists. I would add to this that orientalists, who traditionally prefer "to sit at a separate table," studied the modernization and democratization of Korea from their own corner.

The "Korean question," as a rule, is not considered seriously enough. Carothers (2000) mentions South Korea among a group of countries that "have made somewhat less progress [in terms of democratization] but appear to be still advancing." He also notes that South Korea (like Mexico) "did not go through the paradigmatic process of democratic breakthrough followed rapidly by national elections and a new democratic institutional framework."

Korean terms are romanized according to the McCune-Reischauer system; the names' spelling is original, except for the names of politicians, which are spelt in the most common way. 
Kradin (2008) includes South Korea in the third echelon of modernization (along with the modern countries of Asia, Africa, and Latin America), noting that "some countries (Asian dragons) have made significant achievements," but still he does not underscore South Korea as a separate example. He only makes a footnote that "part of the countries that have gone through modernization and are part of the 'core' and 'semi-periphery' of the world-system have been affected to some extent by authoritarian processes (Cromwell's dictatorship in England, Bonapartism in France, Japan of the Meiji era, Kemalism in Turkey, fascism in Italy and Germany, authoritarianism in South Korea, etc.)."

Eisenstadt (2002) put forward a concept of multiple modernization, based on the idea that modernization and Westernization are not identical, and the Western model is only one of the many options, but did not consider the Korean experience a special case. Mel'vil' in his main works does not mention South Korea at all (Mel'vil', 2000). He only remarks "in brackets" that "it is yet to be convincingly demonstrated that democracy, the way it is understood today, is capable of taking root on the Orthodox, Muslim and Confucian cultural soil."

Kurki (2002) also tries to "contextualize the concepts of democracy," but her experience, too, is confined to examples of feminist or Islamist, but not Confucian democracy. Gunitsky (2018) mentions South Korea in analyzing the third wave of democratization as an example of a combination of the horizontal wave propagation and the socalled "emulation type" where internal factors play the crucial role. However, he enters to his tables only the events of 1988 (the victory of the movement for democratization), while leaving aside the April revolution of 1960 or the uprising in Gwangju in 1980.

Relevant issues were studied by Russian experts on Korea, too. Tolstokulakov $(2003,2007 ; 2009)$ focused on the development of memocratization rather than on comparative analysis. In his opinion, the Republic of Korea belongs to societies that build "formal democracy" as interpreted by R. Dahl (Tolstokulakov, 2003, p. 63). Later Tolstokulakov used the term 'post-traditional society' (2009) to characterize the Republic of Korea. Lantsova (2013) studied the gender aspect of 
democratic transition, while Ilyin (2015) compared the Russian and Korean models, albeit through the lens of classical liberalism.

Among English-speaking authors, I should mention Bruce Cumings (1998), Gregory Henderson (1968), Donald Oberdorfer (1997), Mark Clifford (1993), Gregg Brazinsky (2009), as well as the joint work by Kim Pyong-guk and Ezra Vogel (2011).

Of course, many South Korean authors, starting with Kim Hyung-A (2003, 2011), also studied this subject. Yang Sung Chul (1999) compares the North and the South, Kim Choong Soon (2001; 2007) emphasizes historical development, Sun Kwang-Bae (1997) notes the influence of regionalism, and Kim Sun-Chul connects democratization and social movements (2016). There are remarkable comprehensive studies (Mosler, Lee and Kim, 2018), but a significant part of modern South Korean authors tend to either adjust Korean examples to the global context, or display certain "linearity," although, as Denney (2015) notes, "a linear model for South Korea's economic development and foreign policy overlooks the messiness of history." Another characteristic approach is blaming the lack of democracy in South Korea on the Japanese colonial legacy (Chung, 2006).

Among the works written in Korean some are clearly done in the tradition of classical liberalism (Choe, 2006); some profess the "Asian view of democracy" (Pae, 1988), and some combine these two approaches (Kang, 1994).

In my previous publications (Asmolov, 2003; 2009; 2015a; 2015b; 2017a; 2017b) I wrote about the relevance of "Korean lessons" for modern Russia; the present article is an attempt to find answers to more concrete questions, namely:

1. How relevant is the South Korean example in the context of the current academic discussion on modernization (democratization)?

2. Is modernization in the economic and military spheres accompanied by simultaneous progress in the political and cultural spheres?

3. Is modernization necessarily an analogue of Westernization, with the concomitant borrowing of "democratic values?" 
4. Is there a connection between democratization in South Korea and democratization in the countries of the former socialist bloc, or are they identical? Is it possible to say that events that occur at approximately the same time belong with one "democratic wave?"

5. What elements of modernization or democratic transition could serve as an example for modern Russia?

I will focus on the historic events that took place between 1960 and 1990 as they are important for the purpose of the present study: the overthrow of the Syngman Rhee regime in 1960 and the first unsuccessful democratic experiment of the Second Republic; the modernization breakthrough during the Pak Chung-hee rule (1961-79); the 1980 Gwangju Uprising at the beginning of the Chun Doo-hwan rule, and the fall of the military regime as a result of the "movement for democratization" in 1987-1988.

\section{FAILURE OF THE SECOND REPUBLIC}

TheSyngman Rhee regime was a classic "banana republic," a dictatorship far more authoritarian than the North was at that time. The 60-meter monument to Syngman Rhee on Mount Namsan was the tallest statue in Asia (Baek, 2011, p. 246), the show trials of political opponents resembled the Stalinist purges of 1937 (Henderson, 1968, p. 428), and the national security law envisaged imprisonment of up to five years for "knowingly disseminating false information or distorting the facts and disseminating such facts to benefit the enemy" (Cumings, 1998, p. 343).

Nevertheless, for political reasons, the United States was forced to support it, and the essence of this support was well summarized in the title of one of the chapters in Brazinsky's book Security over Democracy.

American aid during the Rhee rule accounted for half of the budget's revenues (Breen, 2004, p. 125), and in 1953 to 1962 it covered 70\% of South Korean imports and $80 \%$ of capital investments. The country's economy was dependent on agriculture and raw materials. By 1960, in 
terms of GDP per capita ( $\$ 80)$, South Korea was roughly at the level of Nigeria (Chun, 2010). It will be appropriate to recall a remark by a senior U.S. official quoted by Clifford (Clifford, 1993, p. 29): "Korea can never attain a high standard of living. There are virtually no Koreans with the technical training and experience required to take advantage of Korea's resources and effect an improvement over its rice-economy status."

The mass riots sparked by fraud in the March 1960 presidential election and the shooting of protest demonstrators on April 19, 1960 near the presidential palace paralyzed the authorities. On April 26, at an emergency meeting of the National Assembly, a resolution was adopted declaring the results of the presidential election void and demanding the resignation of Syngman Rhee. On the same day, the U.S. ambassador and the commander of U.S. forces in Korea walked through a crowd of applauding demonstrators to demand Syngman Rhee's resignation. The U.S. Department of State issued an official statement about its disagreement with "violations of democracy" in South Korea (Torkunov, Denisov and Lee, 2008, pp. 218-219). Long discontented with Syngman Rhee, Washington had been working on ways of ousting him since the Korean War (Sadakov and Yungblyud, 2018). However, the absence of a suitable candidate and an inappropriate political situation were the main stumbling blocks (Kim, N., 2015).

On April 27, a transitional government was formed, and on April 29, 1960, Syngman Rhee left the country.

However, the first democratic experiment (the so-called Second Republic) failed in almost all respects. The December 29, 1960 elections did not differ from the previous ones in terms of violence and vote rigging (Proshin and Timonin, p. 10), while the authorities' attempt to reorganize the system by decree sent it into a state of collapse.

The new government was experiencing a shortage of managerial personnel untainted by collaboration with the previous regime. As a result, appointees to governmental posts were selected not on the criteria of professional merits, but personal connections or evidenced opposition to the previous authorities. Inferior to the old-style 
predecessors in professionalism, the new officials manifested no less corruption.

Until the moment it rose to power, the opposition had been a typical "alliance against." As soon as it took over, internal discord began. The factionalists continued to place their own interests above the national ones, without paying due attention to the social and economic problems that kept snowballing.

The defeat of the old-timers and the general weakening of the repressive apparatus opened the floodgates to crime: the "neutralized" law enforcement agencies proved to be unable to stop the wave of organized crime and soaring corruption. In addition, many lawenforcement officials fell victim to the mob law, as in most cases the people were guided not by fair retribution, but the desire to settle old scores (Cumings, 1998, p. 345). Students began to take too many liberties. Their mass protests put strong pressure on the government. On several occasions they forced their way into the National Assembly building to rebuke the legislators for the lack of revolutionary morale (Gafurov et al, 1974, p. 378). "Telephone law" was actually replaced by "megaphone law."

As a result, almost a year later, power went to the military in a bloodless coup.

Johnson (1989) believes that the failure of the Second Republic was due to the fact that democratization began before the development of pluralism or liberalization. Indeed, until the proclamation of the Republic of Korea in 1948 Koreans had been unfamiliar with the basics of democracy and had no idea of what democratic institutions were about: neither the elite nor the public at large understood what civil society should be like. In their scheme of things democracy was the democrats' authoritarian regime. Korean society was obviously unprepared to build democracy the way it is understood in the West in terms of creating effective institutions of civil society or using elements of the Western democratic system.

In fact, the political model of the Second Republic in many respects resembled what Carothers called "feckless pluralism." Many elements of the latter would remain in the political culture much longer. 
And the subsequent Pak Chung-hee coup illustrates Mel'vil's (2000) viewpoint that "democratic transitions do not necessarily mean guaranteed transition to democracy and there is no direct correlation between democratization and the level of economic development. Democratization is not a direct product of economic development and modernization." However, a "reverse transition" is also possible, when democratization entails a pullback, as is noted by Gleditsch and Ward (2006).

A chance for sustainable democratization emerged when the social structure of society began to change, and a large middle class emerged in the country, thus providing the basis for building a civil society. However, these processes began only during Pak's rule, when, according to the economic statistics on Seoul of 1969, this group grew to $37.9 \%$ of the population (Torkunov, Denisov and Lee, 2008, p. 292).

\section{A MIRACLE ON THE HANGANG}

With a start-up potential like this, economic growth for Pak was not only a source of prosperity for the country, but also a means to increase the legitimacy of his regime and strengthen national security. After seeing a documentary on the development of the economic potential of North Korea, Pak said: "We will do the same without delay and no worse than they have done" (Tkachenko, 2000, p. 48).

Pak's economic program relied on accelerated industrialization, an export-oriented economy and government control. In 1962, the Economic Planning Directorate, created to coordinate and control economic development, announced the adoption of the first fiveyear plan (not directive, as in the USSR, but an indicative one). Until Pak's death the country's economy in many respects resembled the economy in the Soviet Union (five-year plans existed in South Korea until 1984). Control was carried out by means of licensing and tax administration. The state managed the distribution of loans and export subsidies, controlled foreign trade operations, and regulated prices. The ban on the creation of private banks was a significant leverage of pressure (their denationalization began only in the 1970s): deprived of financial independence, corporations were forced 
to develop the manufacturing industries which the state considered priority ones.

At the same time, in order to prevent possible resistance by the bourgeoisie, Pak kept saying that economic planning should by no means stifle private enterprise, that the spirit of competition should be encouraged, and private property should remain inviolable (Park, 1970, pp. 214-218).

To improve the corporate management system, the emphasis was placed on conglomerates, which were easier and more convenient to manipulate. In fact, Pak Chung-hee personally selected several dozen firms entitled to preferential access to loans and foreign investment in exchange for strict implementation of government instructions. This is how the well-known chebols were created.

Government regulation also manifested itself in the desire to maintain low labor costs, which was achieved by a number of measures: a low living standard at the beginning of the economic growth process; a low share of salary in relation to the profits; long working hours; and rigid official anti-labor policies, with strikes resolutely suppressed by the police and sometimes commando units. Moreover, under an emergency decree of 1971, participation in strikes and other industrial actions was considered a criminal offense (Torkunov, Denisov and Lee, 2008, pp. 260-261). On the other hand, Pak's government encouraged big business' charity and was keen to earn the reputation of a social arbiter, because the trade unions were not yet strong enough, and the protesting workers appealed to the authorities. Before he burned himself on November 13, 1970 in protest against the workers' position, Jeon Tae-il sent a letter to Pak Chung-hee to urge him to take measures to improve the position of the working class (Proshin and Timonin, 1985, p. 75).

Bolstering the businessman's prestige was another achievement Pak has to his credit. Until the mid-1960s "businesspeople" did not enjoy special respect in Korean society, because it was largely believed that they owed their riches to corruption. However, when economic development became a national task and successful entrepreneurs were called industry captains, "a new generation of businessmen appeared in the country, who were not ashamed of making money, 
because they knew that this was to the benefit of the country" (Proshin and Timonin, 1985, p. 78). Clifford agrees with this interpretation (Clifford, 1993, p. 46).

At first, Pak turned Korea into a country-factory capable of buying raw materials, processing them and exporting finished products. The proceeds were used to develop infrastructure and education, as well as to purchase new technologies. By the beginning of the 1970s there emerged an opportunity to switch to capital-intensive industries (metallurgy, shipbuilding, chemical industry), and later to technologyintensive ones (automotive industry, electronics, etc.). The regime also paid due attention to agriculture, as $60 \%$ of the country's population lived in rural areas (Proshin and Timonin, 1985, pp. 63-64). Special programs were launched to encourage cooperation, and housing and communal infrastructures, bathhouses and community centers were built. The establishment of diplomatic relations with Japan in 1965 played a certain role. In this way Pack achieved an influx of $\$ 800$ million worth of Japanese investment into the country. In 1971, Japan's investment in South Korea accounted for $54 \%$ of the overall foreign investment-more than that made by any other country (U.S., 26\%).

As a result, South Korea, whose position had looked hopeless, turned into one of the most dynamic economies on the globe. Already in 1963, South Korea's GDP grew by $9.1 \%$. Throughout Pak's rule its annual growth ranged $8-10 \%$, occasionally rising to $12-14 \%$ and never falling below $6 \%$. At the turn of the 1960s-1970s production grew by an average of $11.1 \%$ a year, export increased by $28.7 \%$, and by 1971 it reached $15.8 \%$ of the GDP. By 1973-1974 South Korea became completely economically independent, and in 1971-1975 it caught up with the North and began to overtake it in terms of economic development.

Johnson (1989) called this model the "capitalist developmental state," where "a collaborative but illiberal relationship between the state and private capital can persist for long periods of time."

\section{MODERNIZATION WITHOUT DEMOCRATIZATION}

The first years after the coup were those of comprehensive austerity measures, as the new regime was keen to gain a firmer foothold. 
From July 12, 1961 to May 10, 1962, there functioned so-called "revolutionary courts." A crackdown on student activists and criminal groups followed. The arrested were forced to walk the streets of Seoul under guard (Eckert and Lee, 1990, p. 361). The same happened to comprador businessmen who had made fortunes during the Syngman Rhee rule. The signs swung around the necks read "I am a corrupt swine" or "I ate the people" (Cumings, 1998, p. 312). The ritual bore a striking similarity to China's Cultural Revolution that was due to follow shortly.

And still, up to 1972 the Pak Chung-hee regime remained moderately authoritarian. There remained an electoral system based on universal and direct suffrage by secret ballot, a multiparty system, a parliamentary system of governance, and the existence of parliamentrestricted political rights and liberal freedoms. Despite the presence of the military in the government, except for the army and the CIA of South Korea (the name of the intelligence service was a replica of the corresponding U.S. abbreviation), persons on active military service held no civilian posts, and the narrow percentage gap between the number of votes cast for different presidential candidates indicates that the authoritarian regime refrained from direct intervention in the electoral process. In the 1963 presidential election, Pak won 46.6\% against $45.1 \%$ of the votes cast for Yun Posun, in 1967, 51.4\% against $40.9 \%$ for Yun; and in 1971, 51.2\% against 43.6\% for Kim Dae-jung (Nohlen, Grotz and Hartmann, 2001).

Such a regime fully corresponded to Carothers' term 'dominant power system': despite certain competition for power by opposition groups and the existence of the main institutional forms of democracy, the change of power seemed unlikely (Carothers, 2000).

However, 1972 saw an outright pullback to autocracy. The fact is that, despite the success of modernization, the regime began to experience a crisis of legitimacy. It was clear that reforms should be continued with the political course remaining the same, while under the current constitution the president could rule the country only for two consecutive terms. Therefore, in 1971, despite violent protests by the opposition (even a state of emergency had to be imposed), Pak 
won the election for a third time, and on October 17, 1972, he staged a constitutional coup that went down in history as "Yusin" (meaning Rejuvenation or Renewal).

The Fourth Republic (1972-1980) is unambiguously regarded as a period of an extremely harsh authoritarian regime and the most dictatorial one in South Korea's modern history. Its most characteristic features were the introduction of a state of emergency, prohibition of any political activity, presidential decrees aimed at direct elimination of the opposition, military courts, and numerous political convictions for violating the presidential decrees (including death sentences), etc. The term 'imperial presidency' (Kim and Vogel, 2011, p. 27) introduced by some authors seems to be quite appropriate.

In 1974-1975 emergency resolutions were adopted to forbid criticism of the constitution or the regime (Kim and Vogel, 2011, p. 394). About 20,000 active opponents of the regime went to jail, while the main opposition leader, Kim Dae-jung, was kidnapped from Tokyo. He was not executed only thanks to quick and effective U.S. intervention (Oberdorfer, 1997, p. 43).

At the same time, the regime remained civil. Johnson (1989) specifically emphasizes this distinction between South Korea and the Latin American juntas. Pak and his team changed their uniforms for civilian clothes and preferred political methods of control to military ones. As a result, most of the regime's functionaries were retirees, and it was the state that controlled the army, rather than vice versa.

The South Korean experience refutes one of Kradin's (2008) main postulates of the modernization theory saying that economic modernization must necessarily be accompanied by gradual political democratization. The impressive rates of economic growth, testifying to successful economic modernization, were not accompanied by serious changes in the political or cultural spheres. Government methods remained authoritarian. Moreover, they became tougher. The successes of the movement for democratization actually date back to the events that preceded the economic miracle by eight to ten years.

It is not accidental that the controversy over the role of Pak Chunghee in contemporary South Korea is reminiscent of Russia's debates 
concerning the personality of Stalin. In both cases, the argument revolves around the relationship between the modernization leap and the price paid for it in terms of the rights and freedoms of citizens. As Rhie Won-Bok writes, "two choices were before him-bread and democracy. He chose bread. True, bread may have been a mere justification for strengthening Pak's dictatorial regime, but there are many who recognize that his strong economic development policies, backed by his dictatorial power, enabled the Koreans to break free from the chains of poverty" (Rhie, 2002, p. 174).

\section{SOVEREIGN DEMOCRACY KOREAN STYLE}

Special attention should be paid to the creation of an official ideology, which was finalized by 1972 with the advent of the chuchesonng doctrine. Soviet specialists on Korean affairs translated this term as 'national subjectivism, apparently with the aim of camouflaging its consonance with North Korea's chuche ideology (Kurmyzov, 2009, p. 263), which has common semantic and philosophical roots.

In the first half of the 1960s, the "theory of administrative democracy" became the political doctrine of the regime. Its essence was that "liberal democracy should be put on a sound nationalist basis," while liberal transformations would be possible only in an economically advanced country.

At the same time, Pak Chung-hee was not a staunch admirer of Confucianism. Nor did he advocate this doctrine as the main factor in South Korea's economic progress, contrary to what Singapore's President Lee Kuan Yew did, for example, in relation to his city state. Pak treated Confucian rules and ceremonies rather scornfully (Mazurov, 1971, p. 184), and in his works, especially early ones, he criticized Confucian dogmatism as one of the reasons for the country's backwardness.

The chuch'esŏng ideology postulated the need for strong authority, hierarchical relations of subordination, and the possibility of social harmony based on national consciousness and justified authoritarianism as a phenomenon inherent in the Korean national culture and Asian culture in general. The conservatism of the 
political system was explained by the specifics of the socio-political development of Asian countries and the role of traditional values (Proshin and Timonin, 1985, p. 100).

Modernization according to chuchesŏng also implied not simple borrowing of Western values, but their transformation through the traditions and realities of Korean society. At the same time, the main role in this transformation was to be played by "sound nationalism" (Tolstokulakov, 2003, p. 101), with the emphasis placed on the need for self-reliance and the strength of the nation state for achieving all identified goals. Pak Chung-hee's rhetoric on this subject was reminiscent of Kim Il-sung's (Tikhomirov, 1998, p. 84).

Chuchesŏng incorporated both traditional Confucian attitudes and principles of government, very different from the European understanding of democracy, and the Korean bourgeois nationalists' views on the specifics of the Korean development path and the impossibility of mechanically transplanting other models to Korean soil.

However, the Korean-type democracy's distancing from Western standards was not as clear-cut as the disassociation of chuche from Marxism-Leninism. The international situation, global trends and pressure from the United States would have never allowed Pak to proclaim an outspokenly anti-democratic program. While insisting on the temporary strengthening of government control, Pak invariably emphasized that he remained committed to his strategy of creating a liberal economic model (Park, 1970).

The cultural policy stemmed directly from this ideology. The government carried out a package of measures to promote Korean culture and encourage interest in the country's history, including the creation of historical, architectural and landscape sites, cultural and recreation centers, historical films and television series, and walking tours for school and university students to historical sites.

To advance nationalism as the core concept of Korean identity, the Korean Institute of Spiritual Culture (now the Academy of Korean Studies) was created as a leading association designed to preserve the heritage of the past and promote national culture and national art. 
Support for national culture proceeded alongside attempts to limit the influence of the West, even in everyday life. In 1972, as chuchesŏng took final shape, a vast campaign against European culture was launched, with bans imposed on Western films, fashion and music (KBS Worldradio, 2015). The "struggle against Western influences" fully complied with the best traditions of totalitarianism. Even the length of women's skirts was subject to regulation.

\section{PRO-DEMOCRACY MOVEMENT CHRONICLES}

After the assassination of Pak Chung-hee his successor began partial liberalization of political life. Choi Kyu-hah preserved the Yusin administration, but canceled Emergency Ordinance No. 9 and promised to hold a referendum on drafting a new constitution and general elections, but his actions were almost instantly quashed by a new generation of the Chun Doo-hwan-led top brass (Breen, 2004, p. 206).

In response to the coup of May 14, 1980, a massive student demonstration began in Seoul. It was called the "Seoul Spring" and proclaimed commitment to the "great march of democratization." However, on May 17-18, 1980, Chun Doo-hwan carried out sweeping arrests of members of the opposition, disbanded the National Assembly and declared full-scale martial law instead of the partial one that had existed before.

In response, the uprising in Gwangju flared up. On May 18$20,1980,18,000$ police and 3,000 paratroops with no experience of dealing with protest demonstrations were moved in. At a certain point bayonets and flame throwers were used against unarmed civilians (Torkunov, Denisov and Lee, 2008, pp. 293-294). According to the average estimates the crackdown caused heavier casualties that the suppression of protests in Beijing's Tiananmen Square (Cumings, 1998, p. 338). The news of the casualties added fuel to the disturbances. Urban residents joined the students. On May 21, 1980, the rebels stormed 16 police stations and other government offices, seized weapons depots and the office of the provincial administration, formed their own authorities to maintain order and 
negotiate with the central government, and arranged for the delivery of food to the city.

The organizers of the uprising belonged to the democratic opposition and expected that the uprising would receive support from the world community, including the U.S., just as it had happened in 1960 (Breen, 2004, p. 210). However, on the morning of May 27, the city was stormed by tanks. Within one and a half hours the main government agencies were retaken by government forces. It should be borne in mind that at that time, according to the Joint Defense Treaty of 1953, the South Korean army was subordinate not so much to the president of South Korea as to the head of the United Command, commander of the U.S. contingent on the Korean Peninsula; so the redeployment of armor units from the demilitarized zone to Gwangju would have been impossible without the U.S. commander's permission.

Brazinsky (2009, p. 255) suspects that this decision "was one of the gravest errors that the United States made in its decades of intimate involvement in Korean affairs," because it significantly delayed the democratization process. Cumings says that despite President Carter's active campaign for human rights around the world the United States preferred to avoid setting a dangerous precedent. Richard Holbrooke played the decisive role in making a political decision. He said the issue was attracting too much attention, while it should be considered more broadly from the point of view of national security interests (Cumings, 1998, pp. 377-378).

During the second half of his rule, Chun Doo-hwan gradually eased the grip. He canceled the most notorious legacies of the military regime (the curfew, blacklists, suppression of the opposition members' civil rights, etc.) and began preparations for the handover of power to his official successor, General Roh Tae-Woo, a classmate and close friend of his.

At the end of April 1986, against the backdrop of a split in the opposition, Chun decided to use force to prolong his term in office, which according to the constitution was to expire in 1987. A wave of protests swept the country again after it became publicly known on January 14, 1987 that a student of the Seoul University, Pak Chonch'ol, 
had been tortured to death during interrogations. Demonstrations started in June and continued unabated. In Seoul, they looked more like a real street war, although the protesters' vanguard still consisted mostly of university students, and not the middle class (Johnson, 1989).

The turbulent events called into question the 1988 Olympic Games in Seoul, which had been conceived as a worldwide presentation of South Korea as a developed country. It also implied a certain political climate. Johnson (1989) stresses that a decision to shift the Games elsewhere "would have humiliated the nation and discredited Chun, who was unable to use force like at Kwangju" in May 1980. The United States, too, exerted pressure on Chun to persuade him to avoid using force to handle the situation. Under common pressure, Roh Tae-Woo on June 29, 1987 suddenly came up with a program for democratic reforms, although he was one of the closest associates of the expresident. On December 16, 1987, a new Constitution was adopted, and on February 25, 1988, for the first time since the establishment of South Korea, a peaceful transfer of power from one president to another took place.

Although democratization in South Korea proceeded alongside transformations in the Soviet Union, the Soviet changes had little significance for the liberalization and partial democratization of conservative authoritarian regimes in Asia makes sense (Brown, 2000).

It is more appropriate to see a certain correlation between democratization in South Korea and the socialist bloc countries, where the drift towards democratization was partly approved and, in some cases, initiated by Moscow. Perry Anderson's statement that "nothing fundamental could change in Eastern Europe as long as the Red Army remained ready for fire" (cited by Gunitsky, 2018, p. 681) is quite applicable to the case of South Korea.

Should Washington prefer in 1960 or in 1987 to stay aloof, the revolution might not have ended in victory the way it happened in 1980. Or it could have won at the cost of far worse bloodshed, according to Schmitter and Brouwer (1999): “The United States conferred democracy upon the Philippines only to see the country 
turn authoritarian and its continuous military presence in South Korea did not prevent the advent of autocracy."

It is worth noting a different point of view, though. Brazinsky claims, for example, that throughout the military rule in South Korea, the U.S. promoted the development of civil society institutions, which later formed the basis of the democratic movement, but it did indirectly, by investing in education and the media, and by carving out opposition politicians from reprisal.

However, even the political struggle of the 1980s should not be regarded as struggle by right and noble civilian democrats against a brutal military regime. Both the opposition and the authorities belonged to the same authoritarian political culture, and no political leader or party offered a democratic alternative (Breen, 2004, p. 217). Kim Sun-Chul makes a similar conclusion: "South Korea’s democratic transition in 1987 was a conservative one, mainly because critical decisions were made by political elites from the top-down without incorporating voices from the bottom-up" (2016, p. 43).

On the one hand, according to 1989 opinion polls, $78.8 \%$ of respondents thought that Korea needed more democracy. On the other hand, according to a joint survey by the newspaper The Chosun Ilbo and the Gallup Institute, published on March 6, 1990, the Koreans placed democratization 16 th on a list of 18 most pressing issues, clearly not considering the issue as crucial (Kim and Kim, 1997, pp. 23-24).

Apparently, such divergence of opinion should be attributed to vulgar perception of democracy. A good example of such an attitude is Kim Dae-jung's statement in response to my lecture at the Moscow State University in 1992. In his opinion, the main signs of democracy were, firstly, the weakening of the repressive system and greater activity by the opposition parties; secondly, positive developments in relations between the North and South; and thirdly, weaker control of information and the freedom of criticism. In other words, democracy was understood as an objective process leading to a change in the situation in the country for the better, more favorable for his political group.

By analogy with Russia, where neither Yeltsin (see Spencer, 2012), nor Putin sincerely engaged in promoting democracy, none of South 
Korean political leaders that might be rated as "democratic" promoted democratic values to an extent greater than it was required for justification of personnel purges aimed at ousting political opponents from governing bodies.

Today's South Korea with its law on national security, a ban on abortions and the "passport-based Internet" (Asmolov, 2015b), is only a partially democratic country, sporadically reminiscent of 'illiberal democracy' in Zakaria's sterms (1997).

To sum it up, the following answers can be given to the questions asked above:

1. South Korea is one of the rare examples of a Third World country's rapid breakthrough to the premier league. It is an impressive example of catch-up modernization that deserves close attention (Ilyin, 2015).

2. Modernization in the economic and military spheres was accompanied by growing authoritarian tendencies from the Third Republic to the Fourth and Fifth. Democratization as modernization of the political sphere began later. I would agree with Kurki's conclusion (2002) that "alternative illiberal models do exist," and modernization is not identical to democratization.

3. Traditionalist theories provided ideological support for modernization. Being unable to avoid mentioning democracy, Pak dwelt at length on "democracy with Korean specifics," in fact contextualizing it. The emergence of the Pak Chunghee military-bureaucratic regime was a logical result of an underdeveloped political system and the absence of democratic traditions in South Korean society based on Confucian principles (Tolstokulakov, 2009).

4. There is no direct connection between democratization in South Korea and democratization in the former socialist bloc countries, but there is certain similarity in the sense that successful and relatively bloodless victories of democracy were associated with "the suzerain's approval." 
Thus, the results of my study of the specific nature of South Korean democracy and/or modernization contradict the basic points of transitology. Just like Carothers (2000), I believe that a more advanced instrument of analysis is needed.

A combination of modernization and authoritarianism, in my opinion, is easy to explain. Catch-up modernization is always an emergency situation, in which it is logical to use authoritarian methods of control as they ensure greater coordination, the possibility of quick manipulation with forces and resources, and prompt operation of the entire system from top to bottom. The disadvantages of such methods fade into the background compared to the importance of what Johnson (1989) called a "determined leadership" capable of imposing the necessary priorities on society. In this particular case, as Clifford (1993) notes, "fear alone does not produce prosperity," and authoritarianism per se is to be matched with competent goal setting and planning.

Regarding the benefits of the Korean lessons for understanding the processes taking place in Russia, it should be noted that neither country has a long democratic tradition similar to that which has brought Europe to its present state of democracy. And this entails a misunderstanding of the meaning of certain concepts or sometimes erroneous adaptation of these concepts to the traditional conditions in Russia or Korea. As a result, in both countries the departure from authoritarian rule did not entail direct transition to democracy (Brown, 2000).

According to Markwick, Yeltsin exploited the etatism tradition of Russian political culture and popular disappointment with party politics (1996), being not a democrat, but a populist. I agree that Russia largely serves as an illustration of the idea that "in many cases political openings, rather than producing genuine democracies, have yielded only 'hybrid regimes' characterized by a mix of autocratic and democratic features" (Møller and Skaaning, 2004).

In this context I. Tolstokulakov (2009) draws attention to the fact that in both countries there is a traditional trend towards building a "strong state," which often upsets the balance between national 
interests and democracy. Tolstokulakov notes that "this does not mean that a choice has to be made in favor of one of the elements of the dilemma, but it significantly complicates the search for their balanced integration. Due to this circumstance, the ratio of higher forms of democracy (such as parliamentary democracy or participatory democracy) and the strong role of the head of state remains a very painful political and legal problem in South Korea and Russia."

This allows for an important forecast: although many would expect "automatic" democratization in modernized Russia or China, this will not necessarily happen.

Both Russia and South Korea sought to separate universal values characteristic of the globalization era from the goals of the United States, which tried to dictate its model of relations to the whole world, passing off its interests as the interests of the international community. In this context, the chuchesong concept is of special importance, especially considering the unsuccessful (in my opinion) attempt to invent its Russian version dubbed "sovereign democracy" (Surkov, 2006) or the desire to find instances of democracy in Russian historyfrom Novgorod to zemstvo-and its combinations with autocracy.

Apparently, one of the reasons for "sovereign democracy" insolvency was that while trying to formulate a special Russian development path the authors of the concept failed to answer the question about the essence of Russia's endemics and the traditional foundations that distinguish it from Western countries and determine its special way. Also, it is not always clear what is to be considered the Russian tradition-values of prerevolutionary Russia, remembered mostly as literary cliches, or the legacy of the Soviet era, in which most of the country's population grew up or lived. Nevertheless, competent cultivation of the sense of national pride, strengthening national identity and national spirit, building the foundations of sound national ethics, and even attitudes towards the "correct understanding of our history" may well become a subject for discussion on what can be borrowed and how it should be applied to the current Russian situation.

The Russian ideology might well take shape as an equivalent of chuchesŏng-a combination of ideas of self-strengthening and 
traditionalism, but tightly pegged to the endemics of a multi-ethnic/ multicultural country. This partly explains why a future ideological platform Putin is now groping for is a blend of symbols inherited from the Russian and Soviet empires. This is well seen in the officially adopted new symbols: the two-headed eagle, the tricolor state flag and tune of the Soviet anthem.

\section{References}

Asmolov, K., 2003. General Pak Chung-hee. Ocherk politicheskoī biografii [General Pak Chung-hee. An essay on political biography]. Seul'skī vestnik, Vol. 77, June, p. 14; Vol. 78, September, pp. 14-15; Vol. 79, November, pp. 1415; Vol. 80, November, pp. 14-16.

Asmolov, K., 2009. Aziatskie tsennosti kak doroga k progressu. Chem ob'yasnit' to, cto ryvok iz tret'ego mira v pervyī sdelali tol'ko strany, vhodyashchie $\mathrm{v}$ konfutsianskii kul'turnyī region? [Asian values as a road to progress. Why the Confucian cultural region countries only made the breakthrough from the Third World to the First?]. Vzaimodeistvie mirovyh tsivilizatsii: istoriya i sovremennost'. Proceedings of the Xth Moscow Academic Conference. M: RUDN, pp. 5-21.

Asmolov, K., 2015a. Uroki koreiskoī istorii XIX-XX vekov dlya sovremennoī Rossii [Lessons from Korean history of the 19th-20th centuries for modern Russia]. Proceedings of the IVth forum "In Memory of Berdyaev", 15-19 August. Vladivostok: DVGU [online]. Available at: <www.isepr.ru/upload/iblock/7eb/ tetradi_15_5.pdf> [Accessed 25 March 2019].

Asmolov, K., 2015b. Yavlyaetsya li Respublika Koreya vitrinoī demoktatii [Is the Republic of Korea a showcase of democracy?]. Novoe vostochnoe obozrenie [online], 12 January. Available at: $<$ ru.journal-neo.org/2015/01/12/yavlyaetsyali-respublika-koreya-vitrinoj-demokratii/> [Accessed 24 March 2019].

Asmolov, K., 2017a. Asian values as a road to progress. Russia in Global Affairs, 15(2), April-June, pp. 190-207.

Asmolov, K.,2017b. Koreīskaya politicheskaya kul'tura:trsaditsii itransformatsiya [Korean political culture: tradition and transformation]. Moscow: Dmitry Pozharsky University.

Baek, Okkyoung, 2011. Understanding Korean history. Seoul: Jimoondang.

Brazinsky, Gregg A., 2009. Nation building in South Korea: Koreans, Americans and the making of a democracy. Chapel Hill: University of North Carolina Press. 
Breen, M., 2004. The Koreans. Who they are, what they want, where their future lies. New York: St. Martin's Griffin.

Brown, Archie, 2000. Transnational influences in the transition from communism. Post-Soviet Affairs, 16(2), pp. 177-200. DOI: 10.1080/1060586x.2000.10641485.

Carothers, Thomas, 2002. The end of the transition paradigm. Journal of Democracy, January, 13(1), pp. 5-21.

Choe, Changjip, 2006. Minjujuŭi-ŭi minjuhwa [Democratization of democracy]. Seoul: Humanit’asŭ.

Chun, Seung-Hun, 2010. Strategy for industrial development and growth of major industries in Korea. Korea Institute for Development Strategy.

Chung, Yong-Hwa, 2006. The modern transformation of Korean identity: Enlightenment and Orientalism. Korea Journal, 46(1), pp. 109-138.

Clifford, Mark L., 1993. Troubled Tiger: businessmen, bureaucrats and generals in South Korea. Armonk, New York: M. E. Sharpe.

Cumings, B., 1998. Korea's place in the sun. A modern history. New York: W. W. Norton.

Denney, Steven, 2015. Modernization theory and uncritical histories: review of South Korea's rise. The Diplomat, 15 February [online]. Available at: $<$ https:// thediplomat.com/2015/02/modernization-theory-and-uncritical-histories-areview-of-south-koreas-rise/> [Accessed 26 March 2019].

Eckert, Carter J. and Lee, Ki-Baik, 1990. Korea old and new. A history. Seoul: Ilchogak Publishers.

Eckert, Carter, J., 2016. Park Chung Hee and modern Korea. The roots of militarism. Cambridge: Harvard University Press.

Eisenstadt, S.N., 2002. Some observations on multiple modernities. In: Sachsenmaier, D., Eisenstadt, S.N. and Riedel, J. Reflections on multiple modernities: European, Chinese and other interpretations, BRILL.

Gafurov, B.G. et al (eds.), 1974. Istoriya Korei (s drevneishih vremen do nashih dnei) [History of Korea (from ancient times till today)], Vol. II. Moscow: Nauka. Gleditsch, K.S., and Ward, M.D., 2006. Diffusion and the international context of democratization. International Organization, 60(4), pp. 911-933. DOI: 10+10170s0020818306060309. 
Gunitsky, S., 2018. Democratic waves in historical perspective. Perspectives on Politics, 16(3), pp. 634-651. DOI:10.1017/s1537592718001044.

Henderson, G., 1968. Korea. The politics of the vortex. Cambridge: Harvard University Press.

Il'in, V., 2015. Modeli kapitalisticheskoī modernizatsii povsednevnosti (na materialah Yuzhnoī Korei i Rossii) [Models of capitalist modernization of everyday life (South Korea and Russia cases)]. In: Koreya $i$ Rossiya: sotsiokul'turnaya dinamika. St. Petersburg: Alteya, pp.153-156.

Johnson, Ch., 1989. The democratization of South Korea: What role does economic development play? Copenhagen Journal of Asian Studies, Vol 4. DOI: http://dx.doi.org/10.22439/cjas.v4i1.1766.

Kang, Mun-gu, 1994. Hanguk Minjujuŭi ŭi Kujo wa Chillo [Structure and direction of Korean democracy development]. Seoul: Hanul.

Kapustin, B.G., 2001. Konets "tranzitologii"? [The end of transitology?]. Polis, Vol. 4. Available at: <http://www.politstudies.ru/article/2922> [Accessed 20 March 2019].

KBS Worldradio, 2015. Koreya: 70 let nezavisimosti [Korea: 70 years of independence]. KBS Worldradio [broadcast, online]. Available at: $<$ http://world.kbs.co.kr/special/kpanorama/russian/program/view. htm?no=10038672\&current_page=1> [accessed 17 March 2019].

Kim, B.W. and Kim, Pan Suk, 1997. Korean public administration. Managing the uneven development. Seoul: Hollym International.

Kim, Choong Soon, 2001, 2007. Tradition and transformation in Korea. Seoul.

Kim, Choong Soon, 2007. Kimchi and IT. Tradition and transformation in Korea. Seoul: Ilchokak.

Kim, Hyung-A and Clark W. Sorensen, 2001. Reassessing the Park Chung Hee era, 1961-1979. Center for Korea Studies, University of Washington.

Kim, Hyung-A, 2003. Korea's development under Park Chung Hee. London: Routledge.

Kim, N.N., 2015. Yuzhnaya Koreya (1945-1948). Politicheskaya istoriya [South Korea (1945-1948). A political history]. Moscow: Vostochnaya literatura.

Kim, Pyŏng-guk and Vogel, Ezra F., 2011. The Park Chung Hee era: the transformation of South Korea. Cambridge: Harvard University Press. 
Kim, Sun-Chul, 2016. Democratization and social movements in South Korea. London: Routledge.

Kradin, N.N., 2008. Problemy periodizatsii istoricheskih makroprotsessov [Problems of periodization of historical macro processes]. In: Grinin, L., Korotaev, A., Malkov S. (eds). Istoriya i matematika: modeli i teorii [History and maths: models and theories]. Moscow: Izdatel'stvo LKI, pp. 166-200.

Kurki, M., 2010. Democracy and conceptual contestability: reconsidering conceptions of democracy in democracy promotion. International Studies Review, 12(3), September, pp. 362-386. DOI: 10.1111/j.1468-2486.2010.00943.x

Kurmyzov, A.A., 2009. Idei chuchhe i ideologiya chechheson: popytka sravnitel'nogo analiza [Chech'e ideas and Chuchesŏng ideology: an attempt at comparative analysis]. In: Koreìskiī poluostrov: vremya novyh vyzovov [Korean Peninsular: time of new challenges]. Moscow: IDV RAN.

Lantsova, I.S., 2013. Gendernye aspekty demokraticheskogo tranzita v Respublike Koreya [Gender aspects of democratic transition in the Republic of Korea]. Vestnik Sankt-Peterburgskogo Universiteta, Series VI. Political Studies. International Relations.

Markwick, R.D., 1996. A discipline in transition: from Sovietology to 'transitology'. Journal of Communist Studies and Transition Politics, 12(3), pp. 255-276. DOI: 10.1080/13523279608415313.

Mazurov, V.M., 1971. Yuzhnaya Koreya i SShA (1950-1970) [South Korea and the USA (1950-1970)]. Moscow: Nauka.

Mel'vil', A. Yu., 2000. Demokraticheskie tranzity, tranzitilogicheskie teorii i postkommunisticheskaya Rossiya [Democratic transitions, transitology theories and post-communist Russia]. In: Politicheskaya nauka $v$ Rossii: intellektual'nyi poisk i real'nost' [Political science in Russia: intellectual search and reality]. Moscow: MONF, pp. 337-368.

Mel'vil', A.Yu., 2007. Demokraticheskie tranzity [Democratic transitions]. In: Solovyov A.I. (ed). Politologiya: Leksikon [Political science studies: a lexicon]. Moscow: ROSSPEN.

Møller, J. and Skaaning, S.-E., 2013. The Third Wave: inside the numbers. Journal of Democracy, October, 24(4), pp. 97-109. DOI: 10.1353/jod.2013.0057.

Mosler, H., Lee, Eun-Jeung, and Kim, Hak-Jae (eds.), 2018. the quality of democracy in Korea. three decades after democratization. Basingstoke: Palgrave Macmillan. DOI: 10.1007/978-3-319-63919-2. 
Nohlen, D., Grotz, F. and Hartmann, C. (eds.), 2001. Elections in Asia. A data handbook. Vol. II. South East Asia, East Asia \& the South Pacific. Oxford.

Oberdorfer, D., 1997. The two Koreas. A contemporary history. New York: Basic Books.

Pae, Songmun, 1988. Minjujuŭi haksŏl: hangug-esŏ sirhŏm [Theory of democracy: practical testing in Korea]. Seoul: Kŭktong sinsŏ.

Pak M.N., 1987. Ocherki po istoriografii Korei [Essays on Korean historiography]. Moscow: Nauka.

Park, Chung Hee, 1970. Our nation's path: ideology of social reconstruction. Seoul: Dong-A.

Park, Chung-hee, 1979. Korea reborn. A model for development. New-Jersey: Prentice-hall [Russian translation online]. Available at: $<$ http://lib.ru/memuary/ singapur/koreareborn.txt $>$ [Accessed 26 March 2019].

Proshin, A.A. and Timonin, A.A., 1985. Neokolonializm SShA i Yuzhnaya Koreya [American Neocolonialism and South Korea], Moscow: Nauka.

Rhie, Won-Bok, et al., 2002. Korea unmasked: in search of the country, the society and the people. Seoul: Gimm-Young International.

Sadakov, D.A. and Yungblyud, V.T., 2018. Diplomaticheskoe obespechenie vmeshatel'stva SShA v Koreiskuyu voīnu. Opyt krizisnogo reagirovaniya [Diplomatic support of U.S. involvement in the Korean War. Crisis response experience]. Vestnik MGIMO-Universiteta, 4(61), pp. 241-261. DOI: 10.24833/2071-8160-2018-4-61-241-261.

Sakwa, R., 2012. Modernisation, neo-modernisation, and comparative democratisation in Russia. East European Politics, 28(1), pp. 43-57. DOI: 10.1080/13523279.2011.636034.

Saxonberg, S. and Linde, J., 2003. Beyond the transitology-area studies debate. Problems of Post-Communism, 50(30, pp. 3-16, DOI: 10.1080/10758216.2003.11656035

Schmitter, P.C. and Brouwer, I., 1999. Conceptualizing, researching and evaluating democracy promotion and protection. EUI Working Paper, SPS, No. 99/9.

Spencer, M., 2012. Spreading peace and democracy: The Russian case. International Journal, 67(1), Winter, pp. 169-182.

Sun, Kwang-Bae, 1997. South Korean politics in transition: democratization, elections, and the voters. In: Regime Change and Regime Maintenance in 
Asia and the Pacific. Discussion Paper No. 20 [pdf]. Available at: <http:// pacificinstitute.anu.edu.au/sites/default/files/resources-links/PSC_Regime_ WP_20.pdf> [Accessed 28 March 2019].

Surkov, V., 2006. Suverenitet - eto politicheskiī sinonim konkurentosposobnosti [Sovereignty is a political byword for competitiveness]. Address to the participants of the United Russia Training Center meeting on 7 February [online]. Available at: $\quad<$ https://web.archive.org/web/20060418035317/http://www.edinros.ru/ news.html?id=111148> [Accessed March 30, 2019].

Tikhomirov, V.D., 1998. Koreīskaya problema i mezhdunarodnye factory (1945 nachalo 80-h godov) [The Korean problem and international factors (1945 - the early 1980s)]. Moscow.

Tkachenko, V.P., 2000. Koreīskīi poluostrov i interesy Rossii [Korean peninsula and Russia's interests]. Moscow: Vostochnaya literatura.

Tolstokulakov, I.A., 2003. Razvitie demokraticheskogo protsessa $v$ Yuzhnoī Koree $v$ period VI Respubliki [Development of the democratic process in South Korea in the Sixth Republic]. Vladivostok: Izdatel'stvo DVGU.

Tolstokulakov, I.A., 2007. Politicheskaya modernizatsiya Yuzhnō̄ Korei. Chast' I [Political modernization in the Republic of Korea. Part I], Vladivostok: Izdatel'stvo DVGU.

Tolstokulakov, I.A., 2009. Politicheskaya modernizatsiya $v$ posttraditsionnom obshchestve (na primere Respubliki Koreya) [Political modernization in posttraditional society (case of the Republic of Korea)]. Doctor of History Thesis [online]. Available at: <http://www.dissercat.com/content/politicheskayamodernizatsiya-v-posttraditsionnom-obshchestve> [Accessed 20 March 2019]. Torkunov, A.V., Denisov, V.I., and Lee, V. F., 2008. Koreīskī poluostrov: metamorfozy poslevoennō istorii [Korean Peninsula: post-war history metamorphoses]. Moscow: OLMA Media Group.

Yang, Sung Chul, 1999. The North and South Korean political systems. A comparative analysis. Seoul: Westview Press.

Zakaria, F., 1997. The rise of illiberal democracy. Foreign Affairs, 76(6), pp. 2243. DOI: $10.2307 / 20048274$. 